\title{
Research on the Reform of Higher Mathematics Teaching in the Transition from Independent College to Applied Undergraduate College

\author{
$X U \mathrm{Hui}^{1, a}, \mathrm{XU} \mathrm{Na}{ }^{2, b}$
} \\ ${ }^{1}$ College of Mathematics and Statistics, Baicheng Normal University, Baicheng,137000,China \\ ${ }^{2}$ Mingren Elementary School, Taobei District, Baicheng,137000, China \\ a358999206@qq.com, b168677791@qq.com
}

Keywords: independent college, application-oriented undergraduate education, higher mathematics

\begin{abstract}
Higher mathematics is the basic course in the education of colleges and universities, which is closely related to the quality of teachers and the quality of students. At present, the reform of teaching mode of higher mathematics in independent colleges in China is striving for improving students' autonomous learning ability and promoting students' autonomous learning. Therefore, how to improve the achievement of independent college students in higher mathematics, and having the high-level teaching means of higher mathematics is the development subject facing to the current independent colleges. This paper focuses on the teaching research of higher mathematics in independent colleges towards applied undergraduate colleges. It hopes to have some reference value for promoting the teaching quality of independent colleges in higher mathematics.
\end{abstract}

\section{Introduction}

With the enrollment scale increasing, our country's higher education gradually entered the field of public education, the students have not only increased in quantity, but also has new requirements on education. As an important mode of independent college running mode of higher education in China, it plays an important role in promoting the level of higher education and teaching on the education reform. The new independent colleges continue to explore in the mode of higher education. For example, the teaching mode of higher mathematics has adopted the application oriented reform idea and achieved good results, which has brought more compound and applied talents for the society.

\section{The Present Situation of Higher Mathematics Teaching in the Independent College}

At present, in the teaching of college courses in higher mathematics curriculum, the main teaching goal is to cultivate the ability of thinking ability and problem students. In order to improve the students' autonomous learning ability and higher mathematics literacy, the reform of student-centered teaching mode of mathematical methods, ideas, theory of all-round increase course the improvement of the times, improve students' active learning and initiative.

At present, the teaching of Higher Mathematics in the independent college includes the following problems:

The second batch of students enrolled in the basic theory is relatively weak. Some students scores are not ideal, lack of self-confidence, so little interest. There is a student in mathematics learning initiative is not strong, after living in a strange environment, the university life does not adapt, passive learning is more obvious. In the study, could not be found for their own learning difficulties, fear is high. Some students do not pay attention to the learning of higher mathematics class, the time spent on learning is not enough. There is a large proportion of the students do not preview and review, a lot of time is wasted [1].

In view of the above problems, the independent college has carried out an analysis of the problems. The main reasons are as follows:

The basic part of the students is poor, for lack of basic elementary mathematics master. When 
encountered difficulties taught by the teacher, or they read without thorough understanding too. Even if the teacher uses various methods to explain it, it is still impossible for the students to master the essence of them.

Some students can't correct their homework in time, and they can't correct mistakes in learning in time. They are not interested in mathematics learning, and can't feel the pleasure from mathematics learning. They also don't take the initiative to ask for help in learning problems.

The relationship between teachers and students is not harmonious, that lead to the students for higher mathematics study interest is not high, the traditional teaching, teachers are the main position in the process of information transmission, the initiative of students is depressed, independent college students prone to inferiority in the psychological, not willing to communicate with teachers, students learning behavior freedom desultoriness, says the biggest obstacle for students interested in learning. Poor students, feeling of discrimination, hurt pride, therefore, do not accept the teachers' hidebound teaching methods, formed a psychological gap insurmountable [2].

\section{Strategies to Improve the Higher Mathematics Teaching Mode in the Independent College}

Independent college students, in addition to a batch of admission, math scores are generally not very good. The second batch, the third batch of students admitted a lot of mathematical knowledge have not mastered, in high school, a part of students' autonomous learning ability is poor, there is the undergraduate college enrollment, especially for fear of mathematics of liberal arts students and do not accept the feeling is very strong. For these reasons, the reform of the teaching model should be taken seriously, no clear goals and motivation to learn, to learn that no difference students to analyze, but also to the traditional teaching method is backward, old and single, and the teaching content of higher mathematics is unreasonable. The lack of professional pertinence to improve.

The discovery learning theory holds that learning these knowledge is a process of rediscovery. Understanding is not a product, but a process.

Independent college students' learning time also have greater autonomy and freedom, physiology, psychology has become mature, also has certain development, has high self-learning ability, has a sense of self, cognitive level. Therefore the application type undergraduate mathematics teaching mode should be a combination of teaching methods of integration. Instead of relying on the traditional teaching mode. For example, teachers in the application of mathematical teaching content, which can guide students to multi angle consciously, multi way to find a solution to the problem, the solution calculation problems and application forms, flexible features, with mathematics knowledge and methods to observation, analysis, encourage students to active thinking, innovative a changeling use, dare to new in order to be different, several solutions to one problem, at the same time for high level application oriented students, psychological and intelligence training, give the mathematical thinking enlightenment, culture the interest and ability to apply mathematics.

At the same time, mathematics education is to teach students to carry out practical activities, let students learn to use mathematical thinking, analysis of mathematics thinking method, to solve practical problems, to observe things around, can also create opportunities for students to participate in mathematical modeling contest, mathematical experiment, so that students feel the important application [3].

The teaching reform of schools of public courses and specialized courses for service. Focusing on the public basic courses of basic knowledge, let the students master the knowledge, but also to let students experience knowledge, the principle, the process of development. In the classroom teaching, let the student experience in knowledge, the principle of generation, knowledge of the development process, can take the form of collective teaching and individual learning, teachers teaching and students' autonomous exploration combined with the model, in order to attract the attention of students, stimulate and promote students' positive thinking. The professional course service, the subjectivity of teachers and students leading role combination, carry out combination teaching mode, including collective discussion cooperative learning, internal and external combination of various forms, to encourage students to try and explore, to enable students to maintain an open and free manner to enable students to actively participate in the activities of 
teaching, to learn life really feels the charm of mathematics.

In specific implementation, teachers should understand the students with the required work basic cultural knowledge and professional knowledge, the active mode of communication, the professional training goal, emphasis on basic courses and specialized courses for the service effect, the learning ability of students in the division of the structure, a detailed understanding of the teaching plan. The teaching contents, teaching methods, curriculum system, basic courses and professional courses down boundaries. For example: mathematics teacher "decentralization" to various professions, understanding of higher mathematics knowledge demand for liberal arts students, does not need the knowledge points, do not speak or speak less, also can add some history class the education, such as to introduce some of the history of mathematics, mathematics and other stories, stimulate interest in learning advanced mathematics for liberal arts students, liberal arts students learn mathematics to reduce fear. In the teaching method but also to the appropriate use of Multimedia Teaching, using the visual and sound effects of multimedia to improve students' interest in learning. For students, the methods of assessment can also be diversified [4].

The use of the teaching of higher mathematics teaching in independent colleges should in the course of study difficulty and wide, adhering to practical first, enough for the principle, pragmatic, face reality, suggestions for reform. By cutting out the superfluous materials should be in the following aspects: one is the application ability of students focus on the reform of evaluation mode of training and holiday increase the content of mathematical modeling, such as assessment methods according to different majors and different professional requirements, the implementation of closed book, book discussions, quizzes, writing thesis, classroom questioning way, avoid wrong, speeding up the construction of test questions, let students develop independent learning atmosphere, stimulate innovation ability. The two is to "service in the technical basic courses and specialized courses" principle, focusing on the problem solving method, the disintegration of thinking, self-learning method, delete some theoretical proof, reduce the difficulty of abstract reasoning, each section should be equipped with the relevant professional and The problem of the exercises, the students after learning have intuitive understanding, the modern mathematical techniques and methods into the content of teaching materials and typical system to increase teaching middle school students take part, will learn to appreciate, improve part content [5].

To strengthen the construction of teachers' team, improving the level of teachers is the key to improve the teaching and teaching reform. So the teacher to continuously improve their professional knowledge, but also learn about the knowledge of other aspects. Especially is the application of technology innovation, new products emerge in an endless stream, application technology brings a new update of knowledge and requirements when the team must have a higher teaching level and academic level of the team, but also in the knowledge structure, age structure is more reasonable, full of vitality. The mathematics teachers of Independent College from many normal universities, comprehensive universities and knowledge of mathematics, to learn better, have a solid foundation of mathematics basic theory however, other aspects of professional knowledge is narrow, the training of students' practical ability is relatively weak, therefore, the team leader The essential and young business backbone, and asked the older teachers can do "biography", "help", "take"; encouragement policy, used to send out, to introduce measures to increase the investment of funds, to send a visiting scholar at home and abroad, colleges and universities learning; between teachers should also be interdisciplinary, cross department of communication and cooperation across disciplines, combining theoretical teaching and experimental teaching, independent college students should be now the demand for knowledge, broaden their horizons of knowledge, provide the prerequisite for the cultivation of applied talents.

The school actively carry out academic exchanges, teaching, actively support and encourage teachers to carry out teaching research and scientific research, for the vertical and horizontal subjects, the cultivation of independent college's own higher applied talents.

To strengthen the communication between teachers and students, to build a harmonious teacher-student relationship. Harmonious, democratic and equal relationship between teachers and students can help students in active learning, give full play to their creativity. Teachers should pay 
more attention to the empathy, the use of the network, mobile phone and other methods and students' communication, also can organize interactive classroom teaching. To understand the change of students' learning and thinking, and adjust according to the situation of students mathematics teaching plan to change the past. The teachers and students exchange basically just stay in the classroom after class, chat, entertainment activities rarely. Increased contact between teachers and students, reduce the difficulty of communication. Let students understand the teacher, more love the teacher, in order to increase the interest in mathematics. As an independent school of high teachers, improve the teaching quality of independent college, accelerate the college mathematics teaching reform, it is necessary Therefore, we should take the initiative to study the teaching and teaching rules of Higher Mathematics in independent colleges, solve the new problems with high sense of responsibility and face new things, and explore the reform methods and implementation plans of higher mathematics, so as to make our due contributions to train more and better talents.

To carry out mathematics stratified teaching mode reform. According to the teaching plan and requirements, for students, will focus on the middle level students, teaching work, pay attention to the specialty, solve the poor do not eat, eat a good foundation. The general practice is to be divided into three teaching part, part of the basic knowledge level of teaching, let students find their own learning environment and content, the second part is to improve the students' interest in learning, and a second as a required course of study, to lay the foundation for follow-up study, junior and senior student as an elective course. The third part is the extended part, explain the history of mathematics, mathematical modeling method of mathematical thinking teaching indoctrination. The basic part of the students are divided into two or three levels, ability of students can be expanded learning, guide him They found the problem, the ability to understand the students in general, basic knowledge to explain, to lay a solid foundation for mathematics. Poor or weak based students, appropriate to reduce the requirements of theoretical knowledge. The teaching speed is too fast, the method from easy to difficult, step by step, through the typical exercise, help they grasp the core knowledge [6].

\section{Conclusion}

The teaching reform of higher mathematics in independent college to undergraduate applied institute transformation is a complex system engineering. It requires teachers starting from the school's point of view, working together with the students, creating a student-centered teaching atmosphere, so as to cultivate students' confidence, determination and creativity. Teachers guide students to improve their learning autonomy and interest in learning. The teachers improve the mathematics teaching quality of independent college as the goal, to cultivate professional strong high-quality talents for the society.

\section{References}

[1] HU Guihua, WANG Shengkui, HU Ke. Introspection on the Hierarchical Teaching of Higher Mathematics in the Independent College[J]. Education and Vocation, 2014, (26):132-133,134.

[2] LI Xiaofei, QIN Chuan. The Study of the Project Learning Method in the Higher Mathematics Experiment Course of the Independent College[J]. Value Engineering, 2013, (30):212-213.

[3] YANG Wenhai. The practice and thinking of higher mathematics stratified teaching in the Independent College[J]. Journal of Jiamusi Vocational Institute, 2013, (12):173-174.

[4] ZHAO Na. Reflections on the integration of mathematical modeling ideas into higher mathematics in Independent Colleges[J]. Ability and Wisdom, 2015, (19):16-16.

[5] MAO Xiaoyan, ZHOU Huijie. The Teaching Reform and Experimental Study of "Higher Mathematics" in the Independent College-Taking the College of Science and Technology of Ningbo University as an example[J]. Industry and Information Technology Education,2016,(1):58-62. 
[6] LIU Shasha. Study on Higher Mathematics Teaching of Higher Mathematics in Independent College[J]. Asia-Pacific Education,2016,(4):120-121. 